\title{
ANALYSIS OF EFFECTS OF SERVICE QUALITY AND LOYALTY ON INTEREST RATES OF BASKETBALL ATHLETES IN SAHABAT BASKETBALL CLUB YOGYAKARTA
}

\author{
Kukuh Hardopo PUTRO ${ }^{1 *}$ \\ SISWANTOYO ${ }^{2}$ \\ Mohd Salleh AMAN ${ }^{3}$
}

Received: December 2019 | Accepted: December 2019 | Published: August 2020

Please cite this paper as: Putro, K. H. et al. (2020). Analysis of effects of service quality and loyalty on interest rates of basketball athletes in Sahabat Basketball Club Yogyakarta, Holistica Journal of Business and Public Administration, vol. 11, iss. 2, pp. 151-160

\begin{abstract}
In business, especially basketball experience an increased very rapidly, both in terms of quality and quantity in Yogyakarta. Customer as the facilities and services the user pays the cost, much influenced by several internal and external factors. These factors have a major influence on the process of the customer to pay a fee to join and dues in Basketball Clubs. This type of research is descriptive with mixed qualitative and quantitative approach, population in this study is the Athlete Club Basketball "Sahabat" of Yogyakarta, with the number of 20 people, the study sample was determined by random sampling. The technique of collecting data using questionnaires. SPSS.21 using data analysis techniques. While looking at the level of loyalty of respondents to the basketball club Yogyakarta "Sahabat", 13 of 20 respondents said well (65\%) and 7 respondents (35\%) had middle loyalty. So from this study showed that customer trust is strongly influenced by the good facilities, appropriate tariffs, staff were nice, the service was very good, and therefore in this study obtained very significant results to customer satisfaction or athletes in the Club Basketball "Sahabat" of Yogyakarta.

Keywords: Quality, Services, Loyalty, Interest Rates, Basketball
\end{abstract}

\section{Introduction}

Business development services are now so good results in competitiveness among private companies are increasingly stringent, so that a company is required to work more

\footnotetext{
1 Master Program in Sports Sciences, Universitas Negeri Yogyakarta, Indonesia, kuhapsport@gmail.com

2 Faculty of Sports Sciences, Universitas Negeri Yogyakarta, Indonesia, siswantoyo@uny.ac.id

${ }^{3}$ Sport Centre, Universiti Malaya, Malaysia, amanms@um.edu.my

* Corresponding author
} 
effectively and efficiently (Phytanza, Burhaein, Sukoco, \& Ghautama, 2018; Yildiz \& Kara, 2012). In busness kususnya basketball experience an increased very rapidly, both in terms of quality and quantity in Yogyakarta. In terms of quality could be better service, compliance costs and the facilities provided to customers (Burhaein, 2017b; Santos, 2003). Customer as the facilities and services the user pays the cost, much influenced by several internal and external factors. These factors have a major influence on the process of the customer to pay a fee to join and dues in Club Basketball.

In the competitiveness of this happening by many perpetrators of companies of various industry looks increasingly tight sports, athletes scramble affect customers or their needs in the market (Avourdiadou \& Theodorakis, 2014; Burhaein, 2017a). Company or club basketball got a customer hearts or athletes when susatu offered by their wills. Therefore, it should be understood and sincerely about user behavior (Kim \& Han, 2013; Pramantik \& Burhaein, 2019). A company or club basketball in terms of activity will be required to manage it properly, so as to have professional management in marketing, human resources, the integrity of a number of factors will be key in the success of the company or club basketball to improve business performance.

Favorable development in all sectors of society have brought changes. Now this community is getting critical, whether in thought or to perform an action (Mosahab, Mahamad, \& Ramayah, 2010). This is an opportunity for organizations / Club Basketball engaged in the service / services. One organization that is engaged in the services / service is Club Basketball "Sahabat" of Yogyakarta. Club "Sahabat" of Yogyakarta was founded in 2013, in the province has more than 20 clubs baasketball, meaning arises between club basketball competition tersebut. From customers in 2013 there has been no research about staaf satisfaction and service to members of the club coach / athlete club "Sahabat" Jogja.

The purpose of this study were (1) the effect of service quality on customer service satisfaction and loyalty club, (2) the effect of costs on customer loyalty club, (3) the effect of interest on customer loyalty club. This research is important because it can determine the strengths and weaknesses of "Sahabat" of Yogyakarta basketball club, so it may be a reference to fix and prepare to face the challenges of competition among club bolababasket in DIY.

\section{Theoritical review}

\subsection{Service quality}

Quality of service is an effort to meet the needs and desires of customers and how to meet customer expectations. Addalah service quality level of excellence as expected and controlled on the level of excellence to meet the wishes of customers (Grönroos, 2001; Mustofa, Mansur, \& Burhaein, 2019).. Quality is beginning to take market share which would result in the level of satisfaction not only need to maintain but also need to be improved to deal with competition (Ardian, Suharjana, \& Burhaein, 2019; Nguyen \& 
Leblanc, 2001). Sesbab by the club must be able to mobilize, organize and coordinate all the activities of a variety of professionals, semi-professionals and non-professionals who are at the club for the same purpose.

Customer satisfaction is the basis of development models of buyer behavior (Olorunniwo, Hsu, \& Udo, 2006). Besides customer satisfaction will be a benchmark to make the entire organization can meet the needs of customers so there will be a sustainable competitive advantage. Consumer satisfaction on all services rendered known company if the company perform a measurement and testing of the consumer. The measurement satisfaction is important in providing a good waiter, the service efficient and effective services. Use of the service quality as a measure of a company is expected to knowing level of customer satisfaction.

With measurement be knew the results of customer satisfaction test, a company can prepare a strategy to be applied in creating consumer loyalty. In concrete results in the field we often see that customer satisfaction is often disregarded or overlooked by either by any individual within the organization. From the customer's mindset often appear many complaints regarding product quality, high price, after-sales warranty is not good. (Soteriou \& Stavrinides, 1997). There are four determinants of quality of service includes direct proof equipment (equipment), staff, price (price) and the program .. The various variables mentioned above are affecting levels of customer satisfaction on the quality of service that is given by the company and the business impact of customer loyalty.

\subsection{Fare}

Rates are something the main thing to be noticed by the sellers in marketing a product. In determining the price of an item will usually do a test market (Nusair, Yoon, Naipaul, \& Parsa, 2010), which means that the price will be set that can be accepted or not by the buyer or customer. Price is the amount of money needed to get their products and services. From these definitions can be noted that the cost that should be paid buyer already includes services that will be provided to the customer is the seller or the buyer.

The determination of the price level usually required classification of costs to help the company's management in achieving goals. For the calculation of the cost of products and services, costs are classified according to the objectives and decision-making fungsinya. To pricing objectives, among others (Purnomo, Tomoliyus, \& Burhaein, 2019; Zineldin, 2006): 1) an increase in sales of 2). repair and retain market 3) Stabilization of prices 4) the achievement of investment targets 5) The maximum profit.

\subsection{Interest}

In the behavior of service provision should be with information and an explanation because it is essential for the interests and to reduce the negative perceptions (Ennew \& Binks, 1999). Therefore, companies can make reference to how this can give a positive impression to interest costumer. 
The fans continue to hold an interest in so far that it becomes part of their everyday interests (Phytanza \& Burhaein, 2019; Pooley, 1980). Sports enthusiasts trying to establish the relationship between the club and the fans, but the formation of a social loyalty empowers fans to increase the influence on interest (Fillis \& Mackay, 2014).

The level of interest in the club sports fans on stakeholders in the network of clubs, played a major role in creating value, which is achieved through the ability to influence social aspects (Zagnoli \& Radicchi, 2010). The relationship between the fans and the team have already referred to the fidelity (Funk \& James, 2006).

\subsection{Loyalty Behavior}

Frequent and strong relations between the partners tend to increase trust and commitment level (Crosby et al., 1990). As a consumer can be loyal because of their belief in the goods and is evidenced in their behavior kpola commitment. Objects attitude in fulfilling loyalty are the service providers, consumer appeal activities.

In the context when measured with a brand level, the result is a geographical area rather than a service provider as an object. In this sense, loyalty attitude is somewhat similar to the concept of attachment to place. On the relationship between psychological commitment, resistance to change, and loyalty behavior. that when examining the psychological commitment in the context of recreation, more appropriate to switch on the behavior of service providers as the attitude object attitude to treat the object settings (Kyle, Graefe, Manning, \& Bacon, 2004).

\section{Method}

This type of research is descriptive with mixed qualitative and quantitative approach (Creswell, J., 2009), population in this study is the Athlete Club Basketball "Sahabat" of Yogyakarta, with the number of 20 people, the study sample was determined by random sampling. The technique of collecting data using questionnaires. SPSS.21 using data analysis techniques.

Hope this research is the actual search in Club Basketball "Sahabat" of Yogyakarta through the following variables:
a. Variable Quality of Service (X1)
b. Variable Cost (X2)
c. Variable Interests Athletes at Club "Sahabat" of Yogyakarta (Y1)
d. Variable Loyalty Club Companion Athletes in Yogyakarta (Y2)
Model and Hypothesis of this research can be described: 
Figure 1 Model and Hypothesis Research

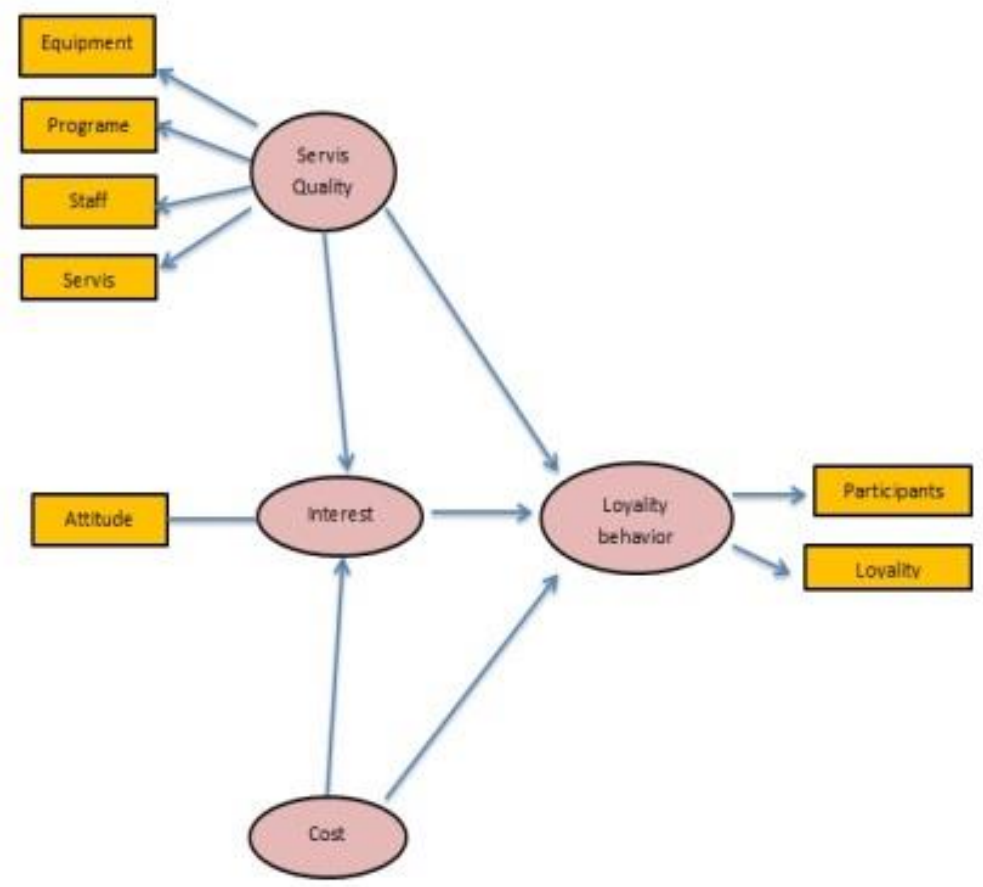

Source: Authors' Research, 2019

\section{Result}

Figure 2 Satisfaction with Tools

\section{EQUIPMENT}

nad aiddle $n$ Good

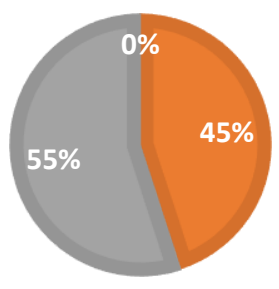

Source: Authors' analysis data, 2019 
The level of satisfaction of athletes to the equipment owned by the club basketball "Sahabat" Yogyakarta by 55\% declare good equipment available, while the ratings were at $45 \%$ and there is nothing to say that the equipment owned by the club basketball Yogyakarta companions in bad condition. This shows that most members of the basketball club have the satisfaction of exercise equipment that is owned by the club.

Figure 3 Diagram of Satisfaction with Staff

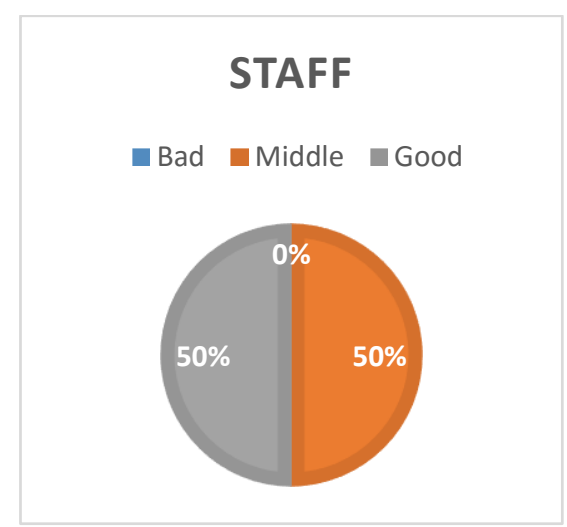

Source: Authors' analysis data, 2019

The study of athlete satisfaction on the performance of staff showed that the staff which is owned by the club is considered by $50 \%$ of respondents have a good performance and $50 \%$ had a middle performance, and $0 \%$ had a poor performance. So it can be seen that the satisfaction of athletes to basketball club Yogyakarta companions still 50:50.

Figure 4 Satisfaction with Training Program

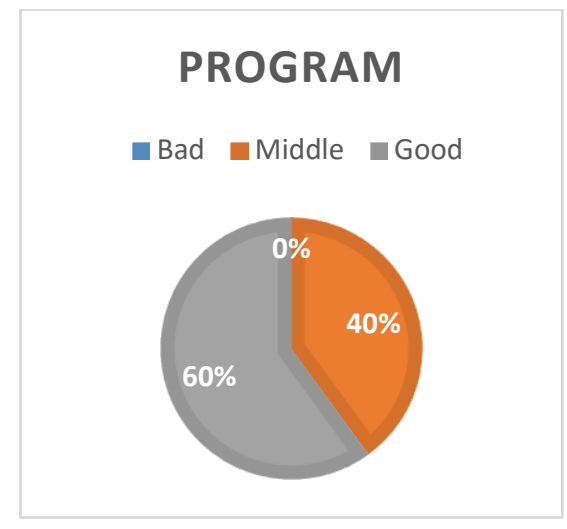

Source: Authors' analysis data, 2019

Results of research conducted can be seen that most of the club athletes shows that athletes satisfied with the training program provided by the club. It can be seen from the 
assessment of respondents to the exercise program given to the club, by $60 \%$ of respondents stated that the exercise program were given a nice, $40 \%$ of respondents stated that the program was being, and $0 \%$ of respondents said in a statement given exercise program bad.

Figure 5 Diagram Satisfaction Of Service

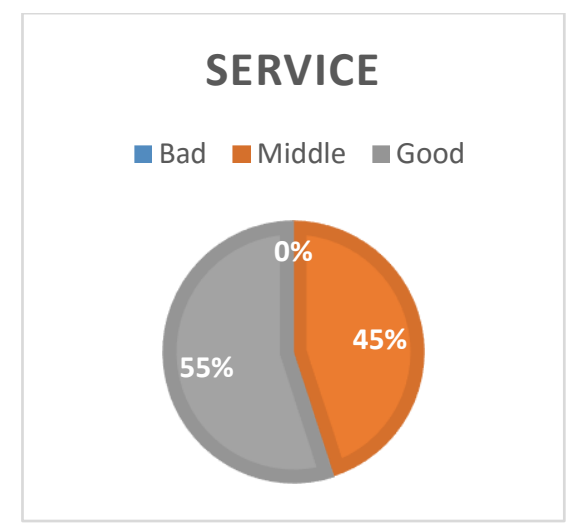

Source: Authors' analysis data, 2019

The level of respondent satisfaction with services provided show that most of the respondents have a good level of satisfaction with the services provided by the club. This is indicated by $55 \%$ of respondents said that the services provided are nice, $45 \%$ of respondents rate the service provided was and $0 \%$ of respondents said that the services provided by the club bad.

Table 1 Table Satisfaction Cost

\begin{tabular}{cccccc}
\hline \multicolumn{6}{c}{ Cost } \\
\hline & frequency & Percent & valid Percent & Cumulative Percent \\
\hline \multirow{2}{*}{ valid } & middle & 11 & 55.0 & 55.0 & 55.0 \\
\cline { 2 - 6 } & nice & 8 & 40.0 & 40.0 & 95.0 \\
\cline { 2 - 6 } & bad & 1 & 5.0 & 5.0 & 100.0 \\
\cline { 2 - 6 } & Total & 20 & 100.0 & 100.0 & \\
\hline
\end{tabular}

Source: Authors' analysis data, 2019 


\begin{tabular}{cccccc}
\hline \multicolumn{5}{c}{ Attitude } \\
\hline & frequency & Percent & valid Percent & Cumulative Percent \\
\hline \multirow{2}{*}{ valid } & middle & 7 & 35.0 & 35.0 & 35.0 \\
\cline { 2 - 6 } & nice & 13 & 65.0 & 65.0 & 100.0 \\
\cline { 2 - 6 } & Total & 20 & 100.0 & 100.0 & \\
\hline
\end{tabular}

Source: Authors' analysis data, 2019

The respondents for satisfaction with the fees charged by the club as much as 11 respondents mengangga fees charged currently, 8 respondents say good, and one respondent stated that the fees charged bad (table 1). From these results it can be seen that most respondents consider the cost given is not too burdensome for the respondents. While looking at the level of loyalty of respondents to the basketball club Yogyakarta "Sahabat", 13 of 20 respondents said well (65\%) and 7 respondents (35\%) have a loyalty that middle (table 2).

So from this study showed that customer trust is strongly influenced by the good facilities, appropriate tariffs, staff were nice, the service was very good, and therefore in this study obtained very significant results to customer satisfaction or athletes in the Club Basketball "Sahabat" of Yogyakarta.

\section{Discussion, and Conclusions}

The results above show the characteristics of the study sample. Quality of service is an effort to meet the needs and desires of customers and how to meet customer expectations. Expressed satisfaction about the facilities and equipment (45\%) Average and (55\%) Good, tools like that to measure the perceived value of customer relationships 19 (Ulaga \& Eggert, 2006).

This study gives the assumption that the customer perception of brand image and corporate image was first evaluated by the perceived quality, while for athletes satisfaction based on comparison of rates and the overall factor is the athlete declared $55 \%$ Middle (40\%) Good (5\%) Bad. To level sample behavioral states (35\%) middle (65\%) good.

Customer trust is strongly influenced by the good facilities, appropriate tariffs, nice staff, a very nice service, and therefore in this study obtained very significant results to customer satisfaction or athletes in the Club Basketball "Sahabat" of Yogyakarta. 
HOLISTICA Vol 11, Issue 2, 2020, pp. 151-160

\section{References}

Ardian, R., Suharjana, S., \& Burhaein, E. (2019). Effect of progressive and repetitive part methods against the accuracy of kicking in football extracurricular students. ScienceRise, 1(7), 40-44. https://doi.org/10.15587/2313-8416.2019.174318

Avourdiadou, S., \& Theodorakis, N. D. (2014). The development of loyalty among novice and experienced customers of sport and fitness centres. Sport Management Review, 17(4), 419431. https://doi.org/10.1016/j.smr.2014.02.001

Burhaein, E. (2017a). Aktivitas Fisik Olahraga untuk Pertumbuhan dan Perkembangan Siswa SD. Indonesian Journal of Primary Education, 1(1), 51-58. https://doi.org/10.17509/ijpe.v1i1.7497

Burhaein, E. (2017b). Aktivitas Permainan Tradisional Berbasis Neurosainslearning Sebagai Pendidikan Karakter Bagi Anak Tunalaras. Jurnal SPORTIF : Jurnal Penelitian Pembelajaran, 3(1), 55. https://doi.org/10.29407/js_unpgri.v3i1.580

Creswell, J., W. (2009). Mapping the Field of Mixed Methods Research. Journal of Mixed Methods Research, 3(2), 95-108. https://doi.org/10.1086/339913

Crosby, L. A., Evans, K. R., Cowles, D., Crosby, L. A., Evans, K. R., \& Cowles, D. (1990). Relationship Quality in Services Selling: An Interpersonal Influence Perspective. Journal of Marketing, 54(3), 68-81. Retrieved from http://www.jstor.org/stable/1251817

Ennew, C. T., \& Binks, M. R. (1999). Impact of Participative Service Relationships on Quality, Satisfaction and Retention: An Exploratory Study. Journal of Business Research 46, 46(2), 121-132. https://doi.org/10.1016/S0148-2963(98)00016-2

Fillis, I., \& Mackay, C. (2014). Moving beyond fan typologies: The impact of social integration on team loyalty in football. Journal of Marketing Management, 30(3-4), 334-363. https://doi.org/10.1080/0267257X.2013.813575

Funk, D. C., \& James, J. D. (2006). Consumer Loyalty: The Meaning of Attachment in the Development of Sport Team Allegiance. Journal of Sport Management, 20(2), 189-217. https://doi.org/10.1123/jsm.20.2.189

Grönroos, C. (2001). Guru's view The perceived service quality concept - a mistake? Managing Service Quality, 11(3), 150-152. https://doi.org/10.1108/09604520110393386

Kim, P., \& Han, J. (2013). Effects of Job Satisfaction on Service Quality, Customer Satisfaction, and Customer Loyalty: The Case of a Local State-Owned Enterprise*. WSEAS TRANSACTIONS on BUSINESS and ECONOMICS, 10(1), 49-68.

Kyle, G., Graefe, A., Manning, R., \& Bacon, J. (2004). Predictors of Behavioral Loyalty Among Hikers Along the Appalachian Trail Predictors of Behavioral Loyalty Among Hikers Along the Appalachian Trail. Leisure Sciences: An Interdisciplinary Journal, 26(1), 99-118. https://doi.org/10.1080/01490400490272675

Mosahab, R., Mahamad, O., \& Ramayah, T. (2010). Service Quality , Customer Satisfaction and Loyalty: A Test of Mediation. International Business Research, 3(4), 72-80. https://doi.org/10.5539/ibr.v3n4p72

Mustofa, F., Mansur, M., \& Burhaein, E. (2019). Differences in the effect of learning methods massed practice throwing and distributed distributed practice on learning outcomes skills for the accuracy of top softball. Journal of Sport Sciences Researches, 4(2), 213-222. https://doi.org/10.25307/jssr.571793

Nguyen, N., \& Leblanc, G. (2001). Corporate image and corporate reputation in customers ' retention decisions in services. Journal of Retailing and Consumer Services, 8(4), 227-236. https://doi.org/10.1016/S0969-6989(00)00029-1

Nusair, K., Yoon, H. J., Naipaul, S., \& Parsa, H. G. (2010). Effect of price discount frames and levels 
HOLISTICA Vol 11, Issue 2, 2020, pp. 151-160

on consumers' perceptions in low-end service industries. International Journal of Contemporary Hospitality Management, 22(6), 814-835. https://doi.org/10.1108/09596111011063106

Olorunniwo, F., Hsu, M. K., \& Udo, G. J. (2006). Service quality, customer satisfaction, and behavioral intentions in the service factory. Journal of Services Marketing, 20(1), 59-72. https://doi.org/10.1108/08876040610646581

Phytanza, D. T. P., \& Burhaein, E. (2019). Aquatic activities as play therapy children autism spectrum disorder. International Journal of Disabilities Sports and Health Sciences, 2(2), 64-71. https://doi.org/10.33438/ijdshs.652086

Phytanza, D. T. P., Burhaein, E., Sukoco, S., \& Ghautama, S. W. (2018). Life Skill Dimension based on Unified Sports Soccer Program in Physical Education of Intellectual Disability. Yaşam $\begin{array}{llll}\text { Becerileri Psikoloji Dergisi, 2(4), 199-205. } & \end{array}$ https://doi.org/https://doi.org/10.31461/ybpd.453865

Pooley, J. C. (1980). The sport fan: A social-psychology of misbehaviour. Canada: Canadian Association for Health, Physical Education and Recreation.

Pramantik, I. A. D., \& Burhaein, E. (2019). Disabilities Sports \& Health Science A Floor Time Approach to Improve Learning Outcomes of the Body Roll to the Side in Adaptive Physical Education Learning: Classroom Action Research Study on Two Cerebral Palsy Students. International Journal of Disabilities Sports and Health Sciences, 2(2), 45-53. https://doi.org/10.33438/ijdshs.652061

Purnomo, I. D., Tomoliyus, T., \& Burhaein, E. (2019). Development of Learning Activities Playing a Ball on a Goal To Improve Manipulative Skills For Lower Class Students. Proceedings of the 1st International Conference on Science and Technology for an Internet of Things. https://doi.org/10.4108/eai.19-10-2018.2281716

Santos, J. (2003). E-service quality : a model of virtual service quality dimensions E-service quality : a model of virtual service quality dimensions. Managing Service Quality, 13(3), 233-246. https://doi.org/10.1108/09604520310476490

Soteriou, A. C., \& Stavrinides, Y. (1997). An internal customer service quality data envelopment analysis model for bank. International Journal of Operations \& Production Management, 7(8), 780-789. https://doi.org/10.1108/01443579710175556

Ulaga, W., \& Eggert, A. (2006). Relationship value and relationship quality Broadening the nomological network of business-to-business relationships. European Journal of Marketing, 40(3/4), 311-327. https://doi.org/10.1108/03090560610648075

Yildiz, S. M., \& Kara, A. (2012). A re-examination and extension of measuring perceived service quality in Physical Activity and Sports Centres (PSC): QSport-14 scale. International Journal of Sports Marketing \& Sponsorship, 13(3), 26-45. https://doi.org/10.1108/ijsms-13-03-2012

Zagnoli, P., \& Radicchi, E. (2010). Sport in Society: Cultures, Commerce, Media, Politics The footballfan community as a determinant stakeholder in value co-creation. (October 2014), 37-41. https://doi.org/10.1080/17430437.2010.520941

Zineldin, M. (2006). The quality of health care and patient satisfaction. International Journal of Health Care Quality Assurance, 19(1), 60-92. https://doi.org/10.1108/09526860610642609 